\title{
SUKCES KRAKOWSKIEGO ARCHIWUM X - STUDIUM PRZYPADKU EWY C.
}

\begin{abstract}
Streszczenie. Krakowskie Archiwum X to zespół złożony z policjantów Wydziału Kryminalnego oraz Wydziału Dochodzeniowo-Śledczego Komendy Wojewódzkiej Policji w Krakowie. Zajmuje się on najtrudniejszymi sprawami kryminalnymi, takimi jak: niewyjaśnione morderstwa popełnione wiele lat temu, tajemnicze zaginięcia osób, wykrywanie seryjnych zabójców. W niniejszym artykule przedstawiono przykłady wielu sukcesów krakowskiego Archiwum X. Zaprezentowano też specyfikę i metody pracy funkcjonariuszy. Szczegółowo opisano jedną ze spraw, dotyczącą tajemniczego zaginięcia Jana L., który 17 lipca 2000 r. wyszedł z domu i nigdy już nie wrócił.
\end{abstract}

Słowa kluczowe: krakowskie Archiwum X, niewyjaśnione morderstwa, zaginięcia osób, analiza materiału dowodowego.

\section{WPROWADZENIE}

Krakowskie Archiwum X powstało 23 stycznia 2004 r. i było jedną z pierwszych takich jednostek w Polsce. Jest to grupa policjantów z Wydziału Kryminalnego i Wydziału Dochodzeniowo-Śledczego Komendy Wojewódzkiej w Krakowie. Od samego początku najważniejszym zadaniem tego zespołu jest wykrywanie „ciemnej liczby zabójstw”, czyli spraw, które na początku traktowane były jako zaginięcia czy wypadki, a w rezultacie okazywały się zbrodniami. Policjanci wchodzący w skład Archiwum X są specjalistami do rozwiązywania najtrudniejszych spraw kryminalnych. W swojej pracy korzystają zarówno z najnowszych zdobyczy techniki, jak i klasycznych metod, takich jak praca operacyjna. Na sukces w ściganiu sprawców składa się również współpraca Archiwum X $\mathrm{z}$ wieloma specjalistami np. profilerami, genetykami, psychologami, antropologami, a także konsultacja $\mathrm{z}$ autorytetami $\mathrm{w}$ dziedzinie kryminalistyki.

W zakresie zainteresowania Archiwum X są sprawy, w których sprawca pozostał niewykryty oraz zgony uznane za zaginięcia, samobójstwa czy nieszczęśliwe wypadki. Dzięki wielomiesięcznym analizom spraw policjanci mogą stworzyć najbardziej trafny scenariusz przestępstwa i wykluczyć fałszywe tropy, które

* Krakowska Akademia im. Andrzeja Frycza Modrzewskiego, Wydział Prawa, Administracji i Stosunków Międzynarodowych, Katedra Kryminalistyki, Kryminologii i Nauk o Policji, paulina222@autograf.pl. 
pojawiają się w sprawach. Śledczy powracają po latach do niewyjaśnionych spraw nie tylko na podstawie dogłębnej analizy zgromadzonego materiału dowodowego, ale również ze względu na pojawienie się nowych przesłanek bądź dowodów w tych sprawach. Rozwój technologii i nauki pozwala na to, aby wyjaśnić przypadki dotąd nierozwiązane. Nie ma wątpliwości co do tego, że zbrodnie sprzed lat należą do najtrudniejszych do wykrycia.

Krakowskie Archiwum X ma na swoim koncie wiele sukcesów. Spośród nich warto wspomnieć o głośnej w latach 90. XX w. sprawie „Hakowego”- mordercy, który w okolicach Zakopanego polował na kobiety, atakując je łańcuchem zakończonym hakiem, a następnie gwałcił i zabijał. Wstrząsnęła ona opinią publiczną w całym kraju. Jednak po latach policjanci z Archiwum X rozwiązali zagadkę tych zbrodni. Kolejną rozpracowaną zagadką była sprawa zagięcia 70-letniego radcy prawnego, który udał się w delegację, ale z niej nigdy już nie wrócił. Do sprawy powrócono po kilku latach, gdy zajęli się nią funkcjonariusze z krakowskiego Archiwum X. Wtedy wyszło na jaw, że za zabójstwem radcy prawnego stoi córka, której pomagała przyjaciółka i konkubina mężczyzny. Policjantom z Archiwum X udało się także rozwiązać zagadkę tajemniczego zaginięcia 45-letniego mężczyzny, który mieszkał na stałe we Wiedniu, a odwiedził matkę w Krakowie i ślad po nim zaginął. Dopiero po 14 latach funkcjonariusze wykryli, że został zamordowany przez szwagra, a jego zwłoki zamurowano w piwnicy domu, który należał do członka jego rodziny (Zajączkowska 2011).

\section{STUDIUM PRZYPADKU EWY C.}

Jedną ze spraw, którą warto szczegółowo przedstawić, a którą po latach udało się z sukcesem rozwiązać, jest sprawa tajemniczego zaginięcia Jana L., który 17 lipca 2000 r. wyszedł z domu mówiąc, że jedzie do swojej narzeczonej i ślad po nim zaginął. Początkiem rozwiązania tajemniczego zniknięcia była wizyta w Krakowie policjantów z Komendy Policji w Zakopanem. Obie jednostki w przeszłości często ze sobą współpracowały przy rozwiązywaniu kilku zaginięć, które określano mianem „niewyjaśnionych”. Funkcjonariusze policji mieli sporo nieoficjalnych informacji, zgodnie z którymi można było wnioskować, że poszukiwany mężczyzna prawdopodobnie nie żyje, a jego zwłoki są ukryte gdzieś na terenie miejsca zamieszkania zaginionego. Główną podejrzaną była jego narzeczona, Ewa C. Policjanci postanowili dokładnie przeanalizować jej życiorys i środowisko, z którego się wywodziła. Warto w tym miejscu przedstawić sylwetkę domniemanej sprawczyni morderstwa.

Ewa C. urodziła się w sierpniu 1979 r. w Zakopanem. Jej rodzicie byli osobami niepełnosprawnymi i z tej racji nie mogli w pełni sprawować opieki ani wychowywać swoich dzieci. Kluczową rolę w wychowaniu Ewy odegrały jej ciotka i babka, które przejęły obowiązki rodzicielskie. Dziewczynka zamieszkała z nimi, 
jednak miała kontakt ze swoimi rodzicami. W szkole podstawowej była uważana na dobrą uczennicę, która nie sprawiała żadnych kłopotów wychowawczych. W 1988 r. ciotka Ewy wyjechała do USA. Był to kluczowy moment, w którym Ewa została sama ze swoją babcią - osobą już obłożnie chorą i wymagającą stałej opieki. W 1993 r. 14-letnia Ewa poznała na lotnisku Jana L. Odwoził on tam swojego brata z żoną, która była kuzynką Ewy. Ich relacja na samym początku znajomości miała charakter koleżeński. Było to też spowodowane dużą różnicą wieku między Ewą a Janem - wówczas 28-letnim mężczyzną. Rodzina dziewczyny była bardzo przeciwna tej znajomości.

Po pewnym czasie owa znajomość nabrała innego charakteru. W ciągu kolejnych miesięcy dochodziło do wielu dobrowolnych stosunków seksualnych między Ewą a Janem. Ponadto Ewa podczas trwania ich związku wysyłała do niego wiele listów, w których pisała o swoich uczuciach. Wyrażała również swoją chęć kolejnych spotkań (Litka, Michalec, Nowak 2016, 126-129). „To moje uczucie było wynikiem mojego młodego wieku oraz sytuacji rodzinnej, gdyż nie byłam wychowywana w miłości. Nie wiedziałam, co to znaczy miłość. Uważałam, że w tym okresie kochałam Jana L., podobnie jak on mnie" (sygn. akt II K 30/05; Zięba 2010, 55). Mężczyzna sprawiał wrażenie odwzajemniania uczucia i okazywał zainteresowanie dalszą kontynuacją znajomości z dziewczyną. Oboje ustalili, że będą się po kryjomu spotykać we wcześniej ustalonych miejscach, aby nikt ich nie zauważył. Tym miejscem był najczęściej las. Już po kilku miesiącach kochankowie zaczęli się kłócić, a ich konflikty stale się pogłębiały. „Jan L. traktował mnie jak swoją rzecz, wyzywał mnie, przezywał" (sygn. akt II K 30/05; Zięba 2010, 55). Był bardzo zazdrosny o Ewę, kontrolował ją, wyzywał, groził. „Mówił, że o ile nie będę przychodzić na umówione spotkania, to podpali dom, w którym mieszkam z babcią oraz że to się dla mnie źle skończy" (sygn. akt II K 30/05; Zięba 2010, 55). Mężczyzna zaczął stosować wobec dziewczyny przemoc fizyczną - bił ją i gwałcił. Cała ta sytuacja zmieniła podejście dziewczyny do ukochanego, którego zaczęła się obawiać.

W październiku 1994 r. zmarła babka dziewczyny; wtedy Ewa zamieszkała samotnie w domu należącym do jej babci. Jan L. miał klucz do tego domu. Mężczyzna często ją odwiedzał i zostawał na noc. Dziewczyna była przemocą notorycznie zmuszana do odbywania stosunków seksualnych. „Każdy gwałt na mojej osobie sprawiał Janowi L. przyjemność, zwłaszcza gdy ja płakałam. Gwałty takie miały miejsce kilka razy w tygodniu przez cały okres naszej znajomości $[\ldots]$ czułam do niego wstręt, złość, nienawiść, obrzydzenie. Przed każdym gwałtem byłam bita" (sygn. akt II K 30/05; Zięba 2010, 55). Ta zmiana stosunku Ewy C. do Jana L. miała odzwierciedlenie w listach, które wysyłała do niego. Poruszała ona w nich również kwestie przemocy fizycznej, prosząc, aby zmienił swoje zachowanie. Na jej ciele były widoczne ślady po licznych pobiciach. Dziewczyna tuszowała je za pomocą kosmetyków, tak aby były niedostrzegalne dla osób postronnych. Mężczyzna groził, że jeśli Ewa będzie się spotykała z kimkolwiek innym niż on, to zabije tamtą osobę i ją samą również. 
W 1998 r. Ewa C. ukończyła szkołę średnią i pracowała w sklepie na stanowisku sprzedawcy. Co więcej, pełniła funkcję referenta kontroli w pewnym zakładzie produkcyjnym. Cały czas była obserwowana przez Jana L., który monitorował godziny jej wyjścia do pracy i powrotu. Ponadto przychodził wieczorami, aby sprawdzić, czy jest sama w domu i czy jest mu wierna. Pogarszająca się z dnia na dzień sytuacja wzbudzała w Ewie coraz większą nienawiść do osoby Jana L. Kilkukrotnie próbowała z nim zerwać, jednak bezskutecznie. Zazdrość mężczyzny rodziła nie tylko przemoc fizyczną, ale również psychiczną w stosunku do kobiety. Całe otoczenie, rodzina, sąsiedzi dobrze wiedzieli o sytuacji dziewczyny trwającej od lat, jednakże nikt się nie interesował jej losem. Nie było żadnych sygnałów pomocy ze strony instytucji, takich jak urząd gminy czy szkoła.

Na początku 2000 r. Ewa postanowiła aplikować mężczyźnie środki uspokajające, które pozostały jej po nieżyjącej już babce. Mężczyzna nie wiedział o tym fakcie. Takie działanie Ewy miało ją uchronić przed kolejnym aktami przemocy, gdyż po lekach Jan L. się uspokajał. W otoczeniu kobiety nie było żadnej osoby, której mogłaby się zwierzyć z tego, w jaki sposób była traktowana. Jan L. zabraniał jej budowania jakichkolwiek relacji z kimś innym niż on. Podczas pracy w zakładzie produkcyjnym Ewa C. poznała Bernarda C., który wraz ze znajomymi podjął się naprawy domu, w którym mieszkała Ewa. Podczas remontu, który trwał dwa lata, poznała Stanisława C., będącego jedną z osób wykonujących remont. $\mathrm{Z}$ biegiem czasu Ewa zaczęła darzyć Stanisława coraz większym uczuciem, co wywołało wzrost zazdrości i coraz większe napady agresji Jana, a także coraz częstsze kontrole. Mężczyzna często obserwował sklep oraz sprawdzał telefonicznie, czy Ewa jest w domu. Trzy tygodnie przed zaginięciem przestał przychodzić do Ewy, ale w dalszym ciągu utrzymywał z nią kontakt telefoniczny.

Co się tak naprawdę wydarzyło 17 lipca 2000 r.? Tego dnia Ewa pracowała do godziny 21.00. Po pracy, wyjątkowo od razu udała się do domu, skąd wykonała telefon do Jana L. Poinformowała go, że już dotarła. Mężczyzna przyjechał do niej na rowerze. Był zdenerwowany tym, że Ewa nie przyszła do niego do domu, jak było zazwyczaj. Podczas kłótni pobił kobietę. Dopiero w momencie, gdy z nosa ciekła jej krew, przestał bić. Rozkazał kobiecie, aby rozebrała go od pasa w dół i odbyła z nim stosunek oralny. Sprzeciw kobiety wywołał w nim gniew, więc siłą wymusił odbycie tego stosunku. Po tym wydarzeniu kobieta udała się do kuchni, aby przemyć twarz i wtedy usłyszała zdanie: „na tym k... nie koniec” (sygn. akt II K 30/05; Zięba 2010, 58). Te słowa wywołały w niej taki gniew, że wzięła z kuchni worek na śmieci i podeszła od tyłu do leżącego mężczyzny, a następnie naciągnęła mu go na głowę, a jego końce zacisnęła na szyi. Do twarzy Jana L. przyłożyła jeszcze poduszkę. Nagły atak wzbudził w nim odruchy obronne, dlatego zaczął szarpać się z kobietą, jednak odcięcie dostępu powietrza przez worek założony na głowę spowodowało uduszenie mężczyzny. „Pękły we mnie wszystkie emocje, które się od tylu lat nagromadziły. Zrobiłam to odruchowo, nie wiedziałam co robię, nie wiedziałam co robię, nie wiem co chciałam osiągnąć 
[...], gdy zobaczyłam, że pokrzywdzony się nie rusza, dotarło do mnie co zrobiłam” (sygn. akt II K 30/05; Zięba 2010, 58).

Ewa C. bała się komukolwiek powiedzieć o tym, co zrobiła. Nie wiedząc, co w takiej sytuacji zrobić z ciałem denata, postanowiła oderwać panele w przedpokoju, który niedawno był remontowany. Odkręciła również płytę paździerzową i wyjęła deski, pod którymi znajdowała się ziemia. W tym oto miejscu wykopała dół, do którego wrzuciła zwłoki mężczyzny oraz rower, którym do niej przyjechał. Resztę rzeczy osobistych, takich jak telefon, ubrania, spaliła w piecu centralnego ogrzewania. Po dokonaniu przestępstwa Ewa C. na wypadek przesłuchania przez policję zapewniła sobie fałszywe alibi, zgodnie z którym w noc zaginięcia mężczyzny przebywała u koleżanki. Co więcej, unikała kontaktów z rodziną Jana L., a podczas rozmów z członkami owej rodziny była bardzo zdenerwowana. Cały czas zarzekała się, że nie wie, co się stało z jej narzeczonym. W maju $2001 \mathrm{r}$. Ewa C. poślubiła Stanisława C. i urodziła mu córkę, a od 2002 r. rodzina zamieszkała w domu kobiety.

Po około czterech latach od tajemniczego zaginięcia Jana L. niewyjaśnioną zagadkę postanowili rozwiązać policjanci z krakowskiego Archiwum X. Swoje działania rozpoczęli od dokładnego przeanalizowania akt sprawy oraz akcji poszukiwawczej, jaka była prowadzona przez funkcjonariuszy zajmujących się wcześniej tą sprawą. Kluczowe było ustalenie tego, w jaki sposób Jan L. zaginął. Z powodu braku jakichkolwiek przesłanek wykluczono, aby tajemnicze zaginięcie było samobójstwem czy też nieszczęśliwym wypadkiem. Sprawa została zakwalifikowana do „ciemnej liczby zabójstw”. Obszernych informacji dotyczących ostatnich dni z życia zaginionego udzielił jego brat, który złożył zeznania w tej sprawie. Brat Jana L. opowiedział o relacji, jaka łączyła Jana i Ewę. Nadmienił też, że dwa dni po zaginięciu poszedł porozmawiać $\mathrm{z}$ kobietą $\mathrm{w}$ tej sprawie, lecz ona wyrzuciła go z domu, po czym unikała kontaktów z rodziną zaginionego, a w ich towarzystwie zachowywała się nerwowo. W aktach sprawy znajdowały się notatki z rozmów przeprowadzonych z Ewą odnośnie do zaginięcia jej narzeczonego. W pierwszej wersji kobieta uważała, że ostatni raz Jana L. widziała 16 lipca 2000 r. W kolejnej wersji Ewa C. zeznała, że widziała go 9 lipca 2000 r., gdy przechodził koło niej. Postanowiono sprawdzić bilingi z telefonu komórkowego zaginionego.

Bilingi wykazały, że mężczyzna od 5 lipca aż do dnia swojego zaginięcia kontaktował się z kobietą. Co więcej, jej numer był ostatnim, na który dzwonił w dniu swojego zaginięcia. Policjanci postanowili sprawdzić także bilingi $\mathrm{z}$ telefonu stacjonarnego w domu, w którym mieszkała Ewa C. W dzień zaginięcia kobieta dwa razy dzwoniła do Jana L. i raz do Stanisława C. Dokładnie analizując wszystkie informacje, można było w tej sprawie postawić hipotezę, zgodnie z którą para aż do dnia zaginięcia mężczyzny kontaktowała się ze sobą, a Ewa C. złożyła fałszywe zeznania, mające na celu odciągniecie uwagi organów prowadzących poszukiwania Jana L. od jej osoby. Poprzednia grupa policjantów 
zajmujących się tą sprawą pobieżnie sprawdziła teren posesji kobiety. Podczas tej czynności nie znaleziono niczego, co by mogło sugerować, że zwłoki mężczyzny mogą znajdować się na jej terenie.

Postanowiono ponownie przesłuchać brata zaginionego. Opisywał on, że w dzień zaginięcia siedział razem z matką w domu, a około godziny 18.00 przyszedł jego brat. Obserwował on przez okno, czy Ewa skończyła już pracę w pobliskim sklepie. Zazwyczaj było tak, że około godziny 20.30 przychodziła do nich do domu, a później razem z bratem szli do domu, w którym mieszkała Ewa. W ten dzień było zupełnie inaczej niż zwykle. Kobieta nie przyszła do domu Jana L., lecz on sam wyszedł około godziny 21.00. Od tamtego czasu brat zaginionego już więcej go nie widział. Dodał też, że ludzie w okolicy mówili, iż widzieli, że kobieta paliła jakieś rzeczy za domem i planowała kolejny remont domu, w którym mieszkała. Dowodem w sprawie, który był bardzo przydatny w określeniu relacji łączącej Jana i Ewę, były listy, które kobieta pisała przez kilka lat ich związku. Pomogły one stworzyć portret zaginionego mężczyzny, jak również po części zrekonstruować przebieg wydarzeń. Policjanci z Archiwum X podejrzewali, że Ewa C. mogła zabić Jana L., jednak nie znaleziono głównego dowodu w sprawie, czyli ciała denata.

4 października 2004 r. funkcjonariusze podjęli decyzję, aby poddać Ewę C. oraz jej męża Stanisława C. badaniom poligraficznym. W trakcie trwania badania kobieta zachowywała się bardzo emocjonalnie. Wykonane badanie wykluczyło udział Stanisława C. w zbrodni. 5 października 2004 r. Ewa C. została aresztowana. W ten sam dzień zarządzono oględziny i przeszukanie domu, w którym mieszkała. Kobieta przyznała się do popełnienia zarzucanego czynu, ponadto wskazała miejsce, w którym ukryła zwłoki Jana L. „Po usunięciu tych rzeczy oraz zdjęciu warstwy ziemni ujawniono zeszkieletowane zwłoki ludzkie, ułożone na wznak z rękoma uniesionymi nad głową. Na czaszce był nałożony worek koloru ciemnoszarego" (sygn. akt II K 30/05; Zięba 2010, 60). W miejscu ukrycia zwłok znaleziono również rower denata. Znalezione zwłoki zabezpieczono i przesłano na badania do Zakładu Medycyny Sadowej w Krakowie.

Oględziny oraz sekcja zwłok wykazały brak dostrzegalnych śladów mechanicznych na kośćcu mężczyzny. W protokole sądowo-lekarskim odnotowano: „Badanie pośmiertne nie pozwala na określenie przyczyny zgonu. Brak uszkodzeń kości nie wyklucza możliwości doznania urazów mechanicznych w okresie bezpośrednio poprzedzającym śmierć. Nie można ani potwierdzić, ani wykluczyć, że do zgonu Jana L. doszło wskutek uduszenia w taki sposób, jaki wynika z wyjaśnień podejrzanej” (sygn. akt II K 30/05; Zięba 2010, 60). W Instytucie Ekspertyz Sądowych w Krakowie wykonano badania włosów Jana L. oraz wydano opinię homogenetyczną, której wynik potwierdził zeznania złożone przez Ewę C.

Badania chemiczno-toksykologiczne przeprowadzone na włosach denata wykazały obecność leków z grupy benzodiazepin. Ta grupa leków uspokajających jest przyjmowana przez osoby cierpiące na lęki i mające problemy z bezsennością. 
Wyniki badań wykazały, że Jan L. przyjmował takie leki przez okres około trzech miesięcy przed swoją śmiercią. Ewa C. w swoich zeznaniach przyznała się, że aplikowała mężczyźnie leki uspokajające, które pozostały jej po nieżyjącej babce. Badania toksykologiczne potwierdziły ten fakt.

$\mathrm{Na}$ zlecenie prokuratury w trakcie trwania procesu Ewa C. była badana przez biegłych różnych specjalności, w tym biegłych psychiatrów i psychologów. Biegli psychiatrzy, którzy przeprowadzali badania 26 listopada 2004 r. w Szpitalu Aresztu Śledczego w Krakowie, w swojej opinii zawnioskowali o obserwację badanej w warunkach szpitala psychiatrycznego. Taka obserwacja psychiatryczna została przeprowadzona od 26 stycznia do 3 marca 2005 r. Biegli przeprowadzający obserwację nie stwierdzili choroby psychicznej, wskazano prawidłowy rozwój osobowości badanej, bez elementów zaburzeń zachowania lub trudności adaptacyjnych w dotychczasowej linii życiowej opiniowanej. Biegli rozpoznali natomiast osobowość niedojrzałą, z reaktywnym stanem depresyjno-lękowym. Ponadto stwierdzili, że nie ma podstaw do zakwestionowania poczytalności Ewy C. w odniesieniu do zarzucanego jej czynu. Okoliczności i motywację określono jako działanie w stanie silnych emocji.

Po przeprowadzonej wcześniej obserwacji wykonano również opinię psychologiczną. Biegły stwierdził u badanej przeciętną inteligencję (IQ = 105), obniżone możliwości koncentracji uwagi i zapamiętywania. Testy psychologiczne nie ujawniły zmian o charakterze organicznym, znajdujących się w ośrodkowym układzie nerwowym. Badanie osobowości wykazało niedojrzałość emocjonalną, niską odporność na stres, brak umiejętności radzenia sobie w sytuacjach trudnych. Badania wykazały również skłonność do zachowań impulsywnych, jak też do obwiniania innych za swoje niepowodzenia i błędy.

16 czerwca 2005 r. Prokuratura Rejonowa skierowała do Sądu Okręgowego akt oskarżenia przeciwko Ewie C. W akcie oskarżenia czyn jej został przypisany jako przestępstwo z art. $148 \S 1$ ustawy z dnia 6 czerwca 1997 r. - Kodeks karny (Dz. U. 1997, Nr 88, poz. 553 ze zm.). Określono, że oskarżona działała w zamiarze bezpośrednim pozbawienia życia Jana L. W toku przewodu sądowego przesłuchano kilku świadków, w tym matkę zamordowanego Jana L., a także inne osoby $\mathrm{z}$ otoczenia sprawczyni i ofiary przestępstwa. Biegli powołani w toku postępowania karnego wykluczyli chorobę psychiczną czy niedorozwój umysłowy, który mógłby w jakikolwiek sposób kwestionować poczytalność Ewy C. w odniesieniu do popełnionego czynu. Ponadto: „Przyjęto działanie w stanie silnego afektu i emocji, warunkowane potrzebą rozwiązywania sytuacji konfliktowej istniejącej między nią a ofiarą, [oskarżona] nie potrafiła znaleźć racjonalnego rozwiązania przewlekającej się, silnie obciążającej jej sytuacji. Podawane przez nią okoliczności bezpośrednio poprzedzające zajście, a to agresja, jaką ujawnił w tym dniu Jan L., są czynnikiem bezpośrednio wyzwalającym te silne emocje jej afektu" (sygn. akt II K 30/05; Zięba 2010, 67). Biegły w swojej opinii odniósł się również do sytuacji rodzinnej kobiety oraz podniósł fakt, że zachowanie Ewy C. 
można traktować jako obronę przed agresją fizyczną i przemocą, jaką stosował wobec oskarżonej Jan L.

15 listopada 2005 r. Sąd Okręgowy w Nowym Sączu uznał Ewę C. winną zarzucanego jej czynu, z tą zmianą, iż „działając pod wpływem silnego wzburzenia usprawiedliwionego okolicznościami, chcąc pozbawić życia Jana L., założyła mu na głowę worek foliowy, a następnie przycisnęła do twarzy poduszkę, na skutek czego zmarł on przez uduszenie, czym dopuściła się występku z art. $148 \S 4$ k.k. i na mocy przepisu wymierzył karę 4 lat pozbawienia wolności" (sygn. akt II K 30/05; Zięba 2010, 67). W wyroku sąd zmienił kwalifikację czynu z art. 148 $\S 1$ k.k. na art. 148 § 4 k.k. Od wyroku pierwszej instancji prokurator złożył apelację, zarzucając obrazę przepisów prawa materialnego, która dotyczyła zmiany kwalifikacji czynu bez uprzedzenia stron procesowych oraz obrazę przepisów postępowania, wpływającą na treść wyroku. Po wyznaczeniu rozprawy apelacyjnej prokurator wycofał swoją apelację. W marcu $2006 \mathrm{r}$. wyrok stał się prawomocny.

\section{ZAKOŃCZENIE I WNIOSKI}

Przedstawione studium przypadku jest jednym z wielu sukcesów, jakie ma na swoim koncie krakowskie Archiwum X. Duża część spraw jest znana opinii publicznej z racji ich nagłośnienia $\mathrm{w}$ mediach bądź programach publicystycznych. Warto sobie uzmysłowić, że gdyby nie praca funkcjonariuszy działających w tej komórce, wszystkie te sprawy do dzisiaj byłyby niewyjaśnione i należały do „ciemnej liczby zabójstw”. Od czego więc tak naprawdę zależy sukces w rozwiązaniu zagadki kryminalnej? Istotną rolę odgrywa tutaj doświadczenie i wiedza śledczych. Dzięki temu mogą oni spojrzeć na daną sprawę w zupełnie inny sposób, niż grupa funkcjonariuszy, która wcześniej się nią zajmowała. Ustalenie prawdy, oprócz doświadczenia i wiedzy z zakresu prawa czy dziedzin pomostowych, zależy również od nawyków, doświadczeń i psychologii na poziomie indywidualnym i zespołowym (Gurgul 2012, 6). Każde kolejne studium przypadku może być cennym doświadczeniem oraz dostarczać dodatkowej wiedzy czy metodyki, która może być pomocna w rozwiązywaniu kolejnych spraw. Nie zmienia to jednak faktu, że każda kolejna sprawa jest inna. Szef krakowskiego Archiwum X, Bogdan Michalec, w jednym z wywiadów przyznał, że niejednokrotnie funkcjonariusze są zaskakiwani sposobem postępowania sprawców, a także pomysłowością, z jaką sprawcy zacierają ślady po popełnionym przestępstwie (Zajączkowska 2011).

Rozprawiając o metodyce pracy funkcjonariuszy, warto wspomnieć o abdukcji, która polega na wnioskowaniu z założeń uznanych za prawdziwe. Specyfiką pracy śledczych, oprócz standardowych postępowań prawnych, kryminalistycznych, jest nieszablonowe myślenie i zdolność do Holmesowskiej abdukcji. Istotna jest umiejętność wyłuskania z natłoku różnych informacji jednego szczegółu, 
który może mieć zasadnicze znaczenie dla sprawy. Przewagą, jaką mają śledczy z Archiwum X nad funkcjonariuszami zajmującymi się sprawą pierwotnie, jest również czas. Poza 30-letnim terminem przedawnienia nie obowiązują ich standardowe terminy obowiązujące w postępowaniu przygotowawczym. Natomiast trudnością, $\mathrm{z}$ jaką muszą się mierzyć policjanci pracujący $\mathrm{w}$ tym wydziale jest brak świeżych śladów biologicznych, które umożliwiłyby powtórne badania, czy też zacieranie się śladów pamięciowych u osób będących świadkami w sprawie.

Rozwój technologiczny i najnowsze osiągnięcia nauki pomagają w ustalaniu sprawców zbrodni. Funkcjonariusze Archiwum X korzystają z systemu AFIS, pozwalającego na porównanie śladu daktyloskopijnego pobranego z miejsca zbrodni z odciskami palców milionów osób zebranych w systemie. Używają poligrafu do badań osób podejrzewanych o dokonanie przestępstwa, a przy poszukiwaniu zwłok korzystają m.in. z helikoptera wyposażonego w kamerę termowizyjną i georadar. Korzystają też z ekspertyz krakowskiego Laboratorium Kryminalistycznego, Instytutu Ekspertyz Sądowych w Krakowie, Polskiego Towarzystwa Kryminalistycznego, Instytutu Psychologii Uniwersytetu Jagiellońskiego, Katedry Medycyny Sądowej Collegium Medicum Uniwersytetu Jagiellońskiego oraz Akademii Górniczo-Hutniczej w Krakowie.

Podsumowując, można powiedzieć, że osiągnięcia krakowskiego Archiwum X znane są nie tylko w Polsce, ale i w Europie. Każda sprawa trafiająca do tej jednostki poddawana jest wnikliwemu badaniu. Niewątpliwie jednym z czynników mających wpływ na sukcesy zespołu Archiwum X jest indywidualne podejście do każdego przypadku oraz brak presji czasu, a zespół nigdy nie stosuje jednego schematu. Wykrywając po latach błędy popełnione przez sprawców, funkcjonariusze podążają za nimi, aż do ich schwytania i doprowadzenia przed sąd. Praca, jaką wykonują funkcjonariusze Archiwum X, rozwiązując stare sprawy, stanowi nieocenioną pomoc dla rodzin osób zaginionych, którzy każdego dnia pytają, co się stało z ich bliskimi i szukają odpowiedzi nawet przez całe życie. Powrót do dawnych, niewyjaśnionych spraw zapewnia spełnienie podstawowych celów organów ścigania w sprawach karnych, takich jak: wykrycie, oskarżenie i ukaranie sprawców zbrodni, nawet jeśli dokonana była kilkanaście lat temu.

\section{BIBLIOGRAFIA}

Gurgul, Józef. 2012. „Sens czy bezsens wracania do starych spraw?”. Problemy Kryminalistyki 3 (277): 5-12.

Konopka, Tomasz, Ewa Kaczor, Adam Gross i in. 2007. „Zabójstwa sprzed lat badane we współpracy z policyjnym Archiwum X". Annales Academia Medicae Stetinesis. Roczniki Pomorskiej Akademii Medycznej 2: 13-16.

Litka, Piotr, Bogdan Michalec, Mariusz Nowak. 2016. Polskie Archiwum X. 119-141. Kraków: Wydawnictwo WAM.

Zajączkowska, Joanna. 2011. Archiwum X istnieje naprawdę. http://wiadomosci.onet.pl/na-tropie/ archiwum-X-istnieje-naprawde/012mp [dostęp 10.02.2017]. 
Zięba, Paulina. 2010. Zabójstwa zwyktych kobiet w sytuacji nadzwyczajnej. Niepublikowana praca magisterska napisana w Katedrze Kryminalistyki, Kryminologii i Nauk o Policji. 54-68. Kraków: Krakowska Akademia im. Andrzeja Frycza Modrzewskiego.

\author{
Paulina Iwanicka
}

\title{
SUCCESS OF THE CRACOW X ARCHIVES TEAM - CASE STUDY OF EWA C.
}

\begin{abstract}
The Cracow X Archives Team is a group composed of police officers of the Criminal Division and the Department of Investigation at the Police Headquarters in Cracow. It deals with the most difficult criminal cases such as unexplained murders committed many years ago, people mysteriously missing, detection of serial killers. This article presents examples of the many successes of the Cracow X Archives Team. It also presents some characteristics and methods of the officers' work. One of the cases has been described in detail. It concerns the mysterious disappearance of Jan L., who on 17 July 2000 left home and never returned.
\end{abstract}

Keywords: the Cracow X Archives Team, unsolved murders, missing people, analysis of evidence. 